\title{
Companies profitability under economic instability: evidence from the manufacturing industry in Russia
}

\author{
Vladislav Spitsin ${ }^{1,2}$, Marina Ryzhkova ${ }^{1,3}$, Darko Vukovic ${ }^{4,5^{*}}$ (1) and Sergey Anokhin ${ }^{1,6}$
}

*Correspondence:
vdarko@hotmail.rs
${ }^{4}$ Finance and Credit
Department, Faculty
of Economics, People's
Friendship University
of Russia (RUDN University),
Miklukho-Maklaya str. 6,
Moscow 117198, Russia
Full list of author information
is available at the end of the
article

${ }^{*}$ Correspondence:

${ }^{4}$ Finance and Credit

Department, Faculty

of Economics, People's

of Russia (RUDN University),

Miklukho-Maklaya str. 6

Moscow 117198, Russia

(0) The Author(s) 2020. This article is licensed under a Creative Commons Attribution 4.0 International License, which permits use, sharing adaptation, distribution and reproduction in any medium or format, as long as you give appropriate credit to the original author(s) and the source, provide a link to the Creative Commons licence, and indicate if changes were made. The images or other third party material in this article are included in the article's Creative Commons licence, unless indicated otherwise in a credit line to the material. If material is not included in the article's Creative Commons licence and your intended use is not permitted by statutory regulation or exceeds the permitted use, you will need to obtain permission directly from the copyright holder. To view a copy of this licence, visit http://creativeco mmons.org/licenses/by/4.0/.
Keywords: Profitability, Enterprises in Russia, Foreign and joint ownership, Production efficiency, Countries with unstable economies

\section{Introduction}

One of the main generally accepted indicators of enterprise performance is profitability. It is of interest to owners of the enterprise and investors as an indicator of the increase in business value and income generation, for managers of the enterprise in terms of the development of the enterprise and its technical modernization, and for the state insofar as the profit is subject to taxation. As the main indicator of the enterprise's activity, it is influenced by many factors that reflect both the production efficiency within the company and the influence of the resource and good markets.

We can assume the influence of two groups of factors affecting profitability: 
- internal factors of the enterprise, reflecting the structure of assets and liabilities, technological features of production, the level of activity of production processes, etc.;

- environmental factors, including both the market conditions for resources and goods, as well as the circumstances prevailing in the economic system at the higher levels (meso-, macro- and megatrends).

Regularities related to the profitability of enterprises are identified in various industries in both developed and developing countries, and extant research takes a special interest in the dynamics of profitability indicators in unstable economic conditions. As in a number of studies (Ahn 2008; Tang 2015; Jeanneret 2015; Griffin 2015; Ahmad et al. 2016; Spitsin et al. 2018), we use the term "economic instability" to refer to the volatility of such external factors as the ruble exchange rate and interest rates (Vukovic et al. 2019; Vukovic et al. 2020). We scrutinize the extent to which the outcome varies depending on the form of ownership, be that domestic enterprises, foreign enterprises or enterprises in the joint form of ownership.

A large number of economic studies are devoted to the analysis of factors affecting the efficiency (profitability) of enterprises. At the same time, economists identify and investigate various groups of factors affecting profitability. For example, in a classic study (Capon et al. 1990), the researchers provided the results of a meta-analysis of 320 studies that looked at 227 variables affecting the financial situation of an enterprise. According to the study's results, indicators such as industry concentration, market share, growth size, capital investment intensity, and advertising intensity emerged as the main explanatory factors of financial performance.

A theoretical approach (the structure-conduct-performance paradigm) assumes a direct impact of industry structure on profitability (Tirole 1988). A different approach (the market-based paradigm) adds into consideration the strategic position of firms within the industry (Welge and Al-Laham 2008). In addition, firm size, market share, growth, age, advertising, R\&D, patents and financial risk have been identified as empirical firm-specific determinants by the previous literature (e.g., Yurtoglu 2004; Chaddad and Mondelli 2013). Firm-specific drivers of profitability are size and financial risk (Gschwandtner and Hirsch 2018).

Very often the study of profitability considers 4 effects: firm, industry, country and period effects. For example, the analysis may suggest that firm effects on profitability for the 2005-2011 periods on the data of the international database of firms are stronger under adversity, whereas industry effects become weaker. Similarly, country main and interaction effects may be considered, with particular attention paid to the emerging economies (Bamiatzi et al. 2016).

The profitability of the company is also associated with the share of the borrowed capital. There are a number of theoretical approaches to regulating the share of borrowed capital in the capital structure of the enterprise:

- Static Trade-off Theory (Kraus and Litzenberger 1973) explains that the share of debt depends on the balance of the costs and benefits. Unfortunately, there is no consensus among researchers in understanding the content of costs and benefits. For 
instance, it may be seen as a balance between the dead-weight costs of bankruptcy and the tax saving benefits of debt. The theory also allows considering agency problems and debt agency conflicts, but does not take into account the information asymmetry and the role of distribution of information in conflicts between insiders and outsiders (Yapa Abeywardhana 2017).

- Pecking Order Theory (Myers and Majluf 1984) suggests that the cost of financing increases with asymmetric information, which results in prioritizing the company's sources of financing from internal financing, to debt, to raising equity. Debt issue is a signal of successful management of a company that can cope with debt pressures and can overcome the agency conflict between managers and owners (Yapa Abeywardhana 2017). Empirical tests of the Pecking Order Theory indicate that it receives less support than the Static Trade-off Theory (Shyam-Sunder and Myers 1999).

- Market Timing Hypothesis (Baker and Wurgler 2002), in contrast to the previously mentioned theories, suggests that the firm tends to issue equity when its market value is rising and vice versa. The capital structure develops under the influence of market conditions, and the capital market does not move to target leverage. It should be noted, however, that a number of researchers have shown the impact of market timing on the firms' capital structure to disappear in the long run (Hovakimian 2006; Alti 2006).

- There are some other potentially relevant brand new theories (including, e.g., credit rating-capital structure hypothesis (Kisgen 2006), but at this point it is hard to investigate them empirically in the Russian context due to data challenges.

Studies of the effect of the share of borrowed capital on the profitability of enterprises in various industries and in different countries have different results. A number of works claim a positive relationship of profitability with the level of short-term debt and in some cases with long-term debt (Negasa 2016).

At the same time, they distinguish the effect of short-term and long-term borrowed capital on ROA (return on assets). If in the short-term period the relationship is positive and significant, in the long-term period the significance of the relationship does not exist (Jain et al. 2017), or even changes the sign (Vaicondam and Ramakrishnan 2017).

Other researchers find the opposite. In the Vietnamese data (Vy and Tra 2016; Le and Phan 2017), the relationship between profitability and leverage is negative, and is robust to the inclusion of control variables as well as firm and year fixed effects. It is a very remarkable finding for Vietnamese enterprises that the smaller the firms, the more profound the relationship. Small and profitable firms tend to have higher incentive to use less debt. In contrast, large firms seem to be indifferent in their debt use due to having greater access to other sources of finance, as well as a larger base of collateral assets. The same relationship is also observed in Thailand (Vithessonthi and Tongurai 2015a, b). Also, along with the negative relationship of debt to total assets and ROE for Vietnamese companies, there is a positive relationship with growth of sales and size of enterprises (Vu and Phan 2016).

According to the meta-analysis (Capon et al. 1990), the impact of the firm's debt load (debt influence on the level of firm) on its financial performance is rather negative (90 out of 147 studies, yet dependencies are insufficient). 
In a Chinese study (Anwar and Sun 2013), the relationship between the level of debt of local firms and the presence of foreign firms on the market was investigated. An increase in foreign presence raises the debt of domestic firms, and its impact on firm investment is also positive. Overall, the impact of foreign presence on the leverage of domestic firms in China's manufacturing sector is negative and relatively large. If we split the firms in two groups (domestically oriented and internationally oriented) as Vithessonthi and Tongurai (2015a, b) did for Thailand, the effect of leverage on performance will be different. For domestically oriented firms it is negative, whereas a positive relationship exists for the internationally oriented ones.

Next, we analyze existing approaches to assessing the effects of attracting foreign investment in the host country. In a sample of Vietnamese firms (Aitken and Harrison 1999), it was found that foreign equity participation was positively correlated with plant productivity but only for small enterprises. On the other hand, for domestically owned companies foreign investment had a negative impact on their productivity. The net impact of foreign investment, taking into account these two offsetting effects, is quite small. The gains from foreign investments appear to be entirely captured by joint ventures. In the Ivory Coast setting (Harrison and McMillan 2003) domestic firms were found to be more credit constrained than foreign firms, and borrowing by foreign firms exacerbated domestic firm credit constraints.

Crisis phenomena in the economy affect foreign and local firms differently. It is natural to assume that foreign multinationals are less linked into the domestic economy, and so are more likely to leave once the economy is hit by a negative shock. But in the case of Ireland (Godart et al. 2012) it is not confirmed: international firms do not flee from Ireland in crisis.

On the contrary, import competition and foreign direct investment discourage entry and stimulate exit of domestic entrepreneurs, the phenomenon referred to as the "crowd out effect" (De Backer and Sleuwaegen 2003). However, the empirical results also suggest that this crowding out effect may be moderated or even reversed in the long run due to the long-term positive effects of FDI on domestic entrepreneurship as a result of learning, demonstration, networking and linkage effects between foreign and domestic firms. Such effects have been identified not only in developed countries (Belgium), but also in the post-socialist countries (Czech Republic) (Kosová 2010). At the same time, the impact of foreign presence on the leverage of domestic firms is negative. In China's manufacturing, an increase in foreign presence increases the debt of value maximizing domestic firms (Anwar and Sun 2015).

Speaking of the relationship of capital structure of domestic, foreign and joint ownership with profitability, one can refer to the data from an Indian study (Chhibber and Majumdar 1999), in which after controlling for a variety of firm and environment-specific factors, firms display relatively superior performance only when property rights belong to foreign owners at ownership levels providing unambiguous control at 51\%. Also, the relationship between foreign entry and profitability of domestic firms has an inverted U-shape (Fu and Wu 2013). Furthermore, we also find that the effect of foreign entry on domestic firm profitability varies according to the ownership structure of domestic firms and the export intensity of foreign newcomers. 
An interesting correlation is observed in Canada regarding the profitability of local firms and firms owned by the US (Shapiro 1983). It is found that US-controlled firms were more profitable than either Canadian- or other foreign-controlled firms. In addition, the study suggested that the higher the degree of non-resident (presumably American) ownership, the higher the profitability of the US-controlled firms. The reverse was true of other foreign firms. These results for the US firms are consistent with the Hymer-Caves and internalization approaches to the multinational corporation.

When studying the influence of factors on profitability in countries with unstable economies, economists, among other factors, single out and investigate the influence of exchange rates.

In Korea (Ahn 2008), small and medium firms are more susceptible to the exchange rate fluctuations than large firms. More importantly, profitability of a more productive firm is found to be less sensitive to the exchange rate fluctuations than that of a less productive firm. Also, there is a relationship between firm size and exposure effects, which also shows that lagged exchange rate changes have significant exposure effects on firm returns (Tang 2015).

An analysis of 84 developed and emerging economies over the 1996-2012 period (Jeanneret 2015) describes effects of exchange rate uncertainty on foreign direct investment. Firms face a choice between participating in foreign markets through exports or investing abroad to relocate production. The most productive firms invest abroad when exchange rate volatility is low and export otherwise, whereas the least productive firms invest abroad when the volatility is high. Other authors (Ahmad et al. 2016) confirm that exchange rate depreciation affects the volume of FDI and promotes growth in the long run. Economic development and inflows are also associated with exchange rates. In Nigeria (Zakari 2017) there was a strong positive relationship between FDI and exchange rate on the one hand, and a weak positive relationship between FDI and GDP on the other hand.

In Colombia (Griffin 2015) no strong evidence was found for the conjecture that real appreciation has, on average, negatively affected the profitability of manufacturing firms. On the contrary, real appreciation may have increased firms' profitability by reducing the cost of imported inputs as Colombian manufacturing firms become more domestically oriented.

Taken as a whole, the literature review suggests that the effects of financial and non-financial factors on firm profitability in the developing countries have not been documented sufficiently and are poorly understood. Moreover, despite the key role of foreign owned and joint enterprises in stimulating the domestic economic activity, extant research rarely distinguishes between the firms based on ownership. Jointly owned enterprises are largely ignored by the received literature. Given the increased government reliance on the technology spillover initiated through participation of foreign and jointly owned firms in the domestic economy, this is a major shortcoming that we try to address in this paper.

In this work, a comprehensive study of the influence of factors on the profitability of enterprises in countries with unstable economies is being conducted. The main division of enterprises is carried out according to the forms of ownership (enterprises in the Russian ( $\mathrm{RO})$, joint (JO) and foreign (FO) ownership), and it is used in all sections of the 
investigation. Additional divisions are carried out by the branches of the manufacturing industry and by the share of borrowed capital in the liabilities side of the balance. Additionally, the impact on the profitability of internal and external factors in an unstable economy is being tested.

The object of the research is manufacturing enterprises in Russia.

The uniqueness of the situation in Russia in 2012-2016 is that:

- For the study period the Russian economy was characterized by instability and crisis manifestations: a strong depreciation of the national currency, a decline in real income of the population, etc.;

- During the study period, there were political tensions, and economic sanctions were imposed on the country with respect to the export and import of high-tech goods. In response, Russia also imposed sanctions, primarily on the products of the food industry.

In this paper, it is planned to assess the impact of this unique situation on the profitability of enterprises in the $\mathrm{RO}, \mathrm{JO}$ and $\mathrm{FO}$ in the context of manufacturing industries.

\section{Methodology}

According to the previously discussed literacy, in this paper the following hypotheses will be tested:

Hypothesis 1. Financial and economic factors have a different impact on enterprises in $\mathrm{RO}, \mathrm{JO}$ and $\mathrm{FO}$ in crisis conditions.

Hypothesis 1.1. Financial factors (internal and external) have a stronger impact on enterprises in $\mathrm{FO}$ and $\mathrm{JO}$ in comparison with enterprises in $\mathrm{RO}$ in crisis conditions.

Hypothesis 1.2. Economic factors have a stronger impact on enterprises in RO in comparison with enterprises in $\mathrm{FO}$ and JO in crisis conditions.

Hypothesis 2. Economic and financial factors have a stronger effect on the net profitability of assets of enterprises in $\mathrm{FO}$ and JO than of enterprises in $\mathrm{RO}$ in each of the analyzed manufacturing industries.

Hypothesis 3. Financial factors have a stronger impact on the net profitability of enterprises' assets as the share of borrowed capital increases.

The object of research includes manufacturing enterprises operating in the Russian Federation. The total number of enterprises included in the sample is 6134. Enterprises are grouped in three ways:

- by ownership forms-enterprises in Russian (RO), foreign (FO) and joint (JO) ownership;

- by branches of the manufacturing industry;

- by the share of borrowed capital in the balance sheet.

Data on financial indicators of enterprises were obtained from the SPARK Information System. We gathered this information for the period from 2012 to 2016. The sample of enterprises of the automotive industry was formed according to the criterion of 
the revenue in 2012-2016 of at least 100 million rubles annually. All enterprises of the automotive industry that met this criterion were included in the sample (solid sample-6208 enterprises). Further, some enterprises with missing values of indicators or having strong deviations of certain indicators (for example, the absolute value of net profitability of assets more than $100 \%$ or the share of borrowed capital more than $300 \%$ of the balance sheet assets) were excluded from the study.

In accordance with these criteria, the following sample of the enterprises was formed:

- 470 enterprises in the foreign ownership;

- 294 enterprises in the joint ownership;

- 5370 enterprises in the Russian ownership;

- In total-6134 enterprises (98.8\% of solid sample).

We used the panel data on $30670(6134 * 5)$ firm-year observations.

The inflation data were obtained from the reports of the Federal State Statistics Service, the data on average annual exchange rates were obtained from the ruxpert.ru, and the data on currency exchange rates at the end of the year and interest rates on loans were obtained from the website of the Central Bank of the Russian Federation.

\section{Models and variables}

According to the recent literature (Vaicondam and Ramakrishnan 2017; Chatterjee 2012; Habrosh 2017), the dependent variable is explained by the net profitability of assets. This indicator characterizes the profitability and efficiency of enterprises.

Independent variables For the independent variables we used:

A. Control variables (Vaicondam and Ramakrishnan 2017; Chatterjee 2012; Habrosh 2017):

1. Size of the enterprise calculated as a natural logarithm of revenue. Revenue was adjusted for the inflation index;

2. Fixed assets share calculated as the share of fixed assets in total assets.

3. Current liquidity ratio.

B. Production efficiency

4. Gross profitability of sales-this variable characterizes production efficiency and is defined as the ratio of gross profit (the difference between revenue and production cost) to revenue.

C. Financial factors

5. Share of the borrowed capital, which is defined as the ratio of borrowed capital to the liabilities side of the balance. It allows assessing the impact of borrowed capital on the net return on assets and the consistency of the obtained results with the Static Trade-off Theory and the Pecking Order Theory (Kraus and Litzenberger 1973; Myers and Majluf 1984).

6. Average interest rates on short-term (up to 1 year) loans to enterprises at the end of the year. Note that in the conditions of the crisis (2014-2015) there was an increase in interest rates on loans; 
7. Average annual exchange rate of the ruble to the dollar. During the crisis period of 2014-2015, the ruble exchange rate to the dollar increased in absolute terms, i.e., the ruble fell. In 2012, the exchange rate was 31.08 rubles/dollar, and in 2016 the rate became 66.08 rubles/dollar;

8. Share of foreign owners (ShareFO), which corresponds to the share of foreign owners in the authorized capital of the enterprise. For RO (domestic) enterprises ShareFO equals 0 , for enterprises in FO ShareFO equals 1 , for enterprises in JO ShareFO it is in the range from 0 to 1 ;

9. Ruble's depreciation is the difference of the ruble-dollar exchange rates at the end of the current and the end of the previous year. If this difference is greater than 0 , the ruble rate has decreased relative to the dollar. If this difference is less than 0 , the ruble rate has increased relative to the dollar.

The variables exhibited reasonable correlations as could be seen in Table 1.

A strong correlation (0.75) is present only between the variables: ruble's depreciation and average interest rates. However, in its pure form, the first variable (ruble's depreciation) is not used in models, only when multiplied with ShareFO and the share of borrowed capital. There is no strong correlation between other variables, and thus we can use them in the regression analysis (in Table 2).

To test the differences between enterprises in the $\mathrm{RO}$ and enterprises with foreign capital (enterprises in FO and JO), the following variables were additionally used in the models (see Table 2):

D. Production efficiency

10. Gross profitability of sales * ShareFO-calculated by multiplying the level of gross margin of sales to the share of foreign capital in the capital of the enterprise (FS 0 for $\mathrm{RO}, 1$ for $\mathrm{FO}$ ).

E. Financial factors

11. Share of borrowed capital "ShareFO;

12. Share of borrowed capital * ShareFO * Ruble's depreciation;

13. Average interest rates * ShareFO;

14. Average annual exchange rate * ShareFO.

\subsection{Models and estimation}

Given the multi-year nature of our data, we used panel data techniques to test our hypotheses.

Diagnosis of the panel model with control variables for the sample of 6134 enterprises showed the following:

1. a simple regression model based on the method of least squares is estimated as not adequate, with preference being given to models with fixed effects based on Wald test statistic (pW $\ll 0.001$ ), as well as models with random effects based on BreuschPagan test statistic (pB-P $\ll 0,001)$; 


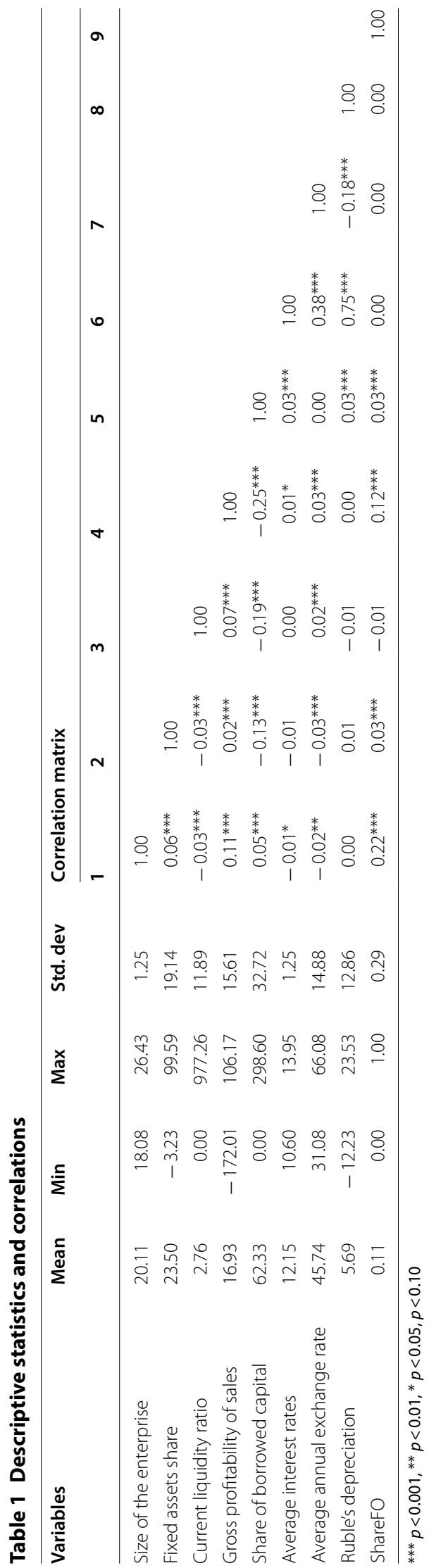


Table 2 Types of investigated models of net return on assets

\begin{tabular}{|c|c|c|c|c|c|c|c|}
\hline & Model 1 & Model 2 & Model 3 & Model 4 & Model 5 & Model 6 & Model 7 \\
\hline Intercept & V & V & V & V & V & V & V \\
\hline Size of the enterprise & V & V & V & V & V & V & V \\
\hline Fixed assets share & V & V & V & V & V & V & V \\
\hline Current liquidity ratio & V & V & V & V & V & V & V \\
\hline Gross profitability of sales & - & V & V & V & V & V & V \\
\hline Share of borrowed capital & - & - & V & V & V & V & V \\
\hline Average interest rates & - & - & - & V & V & V & V \\
\hline Average annual exchange rate & - & - & - & V & V & V & V \\
\hline Gross profitability of sales * ShareFO & - & - & - & - & V & V & V \\
\hline Share of borrowed capital * ShareFO & - & - & - & - & - & V & V \\
\hline $\begin{array}{l}\text { Share of borrowed capital * ShareFO } \\
\text { * Ruble's depreciation }\end{array}$ & - & - & - & - & - & V & V \\
\hline Average interest rates * ShareFO & - & - & - & - & - & - & V \\
\hline $\begin{array}{l}\text { Average annual exchange rate * } \\
\text { ShareFO }\end{array}$ & - & - & - & - & - & - & V \\
\hline
\end{tabular}

2. Hausman test statistic shows (chisq $=1491.9, d f=3, p$ value $<2.2 \mathrm{e}-16) \mathrm{pH} \ll 0.001$. Low $p$ values indicate a weak null hypothesis about the adequacy of the model with random effects, giving the advantage to models with fixed effects. That is, the preference should be given to models with fixed effects.

Specifically, we utilized fixed effects estimation procedure. In all, we report seven tested models.

To minimize the multicollinearity concerns, all predictor variables are standardized (Marquardt 1980).

Option 1 Realization of models No. 1-4 for the full sample of enterprises (6134) and separately for samples of enterprises in the FO, RO and JO:

Full sample of enterprises of all forms of ownership;

1.1 Enterprises in $\mathrm{FO}$;

1.2 Enterprises in JO;

1.3 Enterprises in RO.

Option 2 Implementation of models No. 1-7 by branches of the manufacturing industry. Within the framework of this paper, the following industries were investigated (according to OKVED 1.2., which corresponds to the European classification of Economic Activities NACE Rev. 1.1.):

2.1 DM (automotive industry) - as part of the DM manufacture of transport equipment;

2.2 DK-manufacture of machinery and equipment n.e.c.;

2.3 DG-manufacture of chemicals, chemical products and man-made fibers;

2.4 DJ-manufacture of basic metals and fabricated metal products; 
2.5 DL-manufacture of electrical and optical equipment;

2.6 DA-manufacture of food products, beverages and tobacco.

Option 3 Implementation of models No. 1-7 for samples of enterprises with different shares of borrowed capital:

3.1Full sample of enterprises

3.2Enterprises with a share of borrowed capital for 2012-2016 less than 50\% annually $(<50 \%)$;

3.3Enterprises with a share of borrowed capital for 2012-2016 annually exceeding 50\% $(>50 \%)$.

\section{Results and discussion}

\subsection{Option 1}

The study of the influence of ownership on the net profitability of assets.

The four regression models formed above are presented in Table 3. The coefficients and standard errors are given according to model 4.

For all four cases (full sample, enterprises in FO, enterprises in JO, enterprises in RO), a highly significant impact on the net return on assets of control variables was revealed:

- positive impact-enterprise size;

Table 3 Regression results (fixed effects estimates, robust estimates). Source: calculated by the authors according to data (SPARK: Information system. Interfax (Russia) 2018)

\begin{tabular}{lllll}
\hline & Full sample & Enterprises in FO & Enterprises in JO & Enterprises in RO \\
\hline Size of the enterprise & $6.80(0.29)^{\mathrm{b}}$ & $7.40(1.43)^{\mathrm{b}}$ & $5.48(1.48)^{\mathrm{b}}$ & $6.90(0.28)^{\mathrm{b}}$ \\
Fixed assets share & $-1.25(0.14)^{\mathrm{b}}$ & $-2.25(0.77)^{\mathrm{a}}$ & $-1.38(0.73)$ & $-1.17(0.15)^{\mathrm{b}}$ \\
Current liquidity ratio & $-0.10(0.09)$ & $-3.64(1.58)$ & $-0.53(1.61)$ & $-0.09(0.09)$ \\
Gross profitability of sales & $5.17(0.22)^{\mathrm{b}}$ & $7.21(1.02)^{\mathrm{b}}$ & $4.02(0.99)^{\mathrm{b}}$ & $5.09(0.22)^{\mathrm{b}}$ \\
Share of borrowed capital & $-6.44(0.23)^{\mathrm{b}}$ & $-8.30(0.88)^{\mathrm{b}}$ & $-8.64(1.30)^{\mathrm{b}}$ & $-5.96(0.24)^{\mathrm{b}}$ \\
Average interest rates & $-0.64(0.05)^{\mathrm{b}}$ & $-3.11(0.28)^{\mathrm{b}}$ & $-1.58(0.26)^{\mathrm{b}}$ & $-0.37(0.04)^{\mathrm{b}}$ \\
Average annual exchange rate & $0.04(0.05)$ & $1.49(0.30)^{\mathrm{b}}$ & $0.91(0.29)^{\mathrm{a}}$ & $-0.14(0.05)^{\mathrm{a}}$ \\
Intercept & $5.89(0.00)^{\mathrm{b}}$ & $-1.88(1.04)$ & $2.19(0.74)^{\mathrm{a}}$ & $6.75(0.03)$ \\
& & & & {$[p<0.001]$} \\
Model 1 $R^{2}$ & 0.070 & 0.051 & 0.077 & 0.077 \\
Model 2 $R^{2}$ & 0.165 & 0.149 & 0.140 & 0.178 \\
Model 3 $R^{2}$ & 0.266 & 0.277 & 0.240 & 0.273 \\
Model 4 $R^{2}$ & 0.272 & 0.330 & 0.262 & 0.276 \\
$\Delta R^{2}$ of production efficiency & 0.095 & 0.098 & 0.063 & 0.101 \\
$\Delta R^{2}$ of financial factors & 0.107 & 0.181 & 0.122 & 0.098 \\
Including -internal & 0.101 & 0.128 & 0.100 & 0.095 \\
External & 0.006 & 0.053 & 0.022 & 0.003 \\
Number of enterprises in the sample & 6134 & 470 & 294 & 5370
\end{tabular}

Standard errors are in parentheses. The coefficients and standard errors are given according to model 4 . All constructed models (models No. $1-4$ ) are highly significant for all samples ( $p \ll 0.0001)$

a $\Delta R^{2}$ of production efficiency is calculated as the difference of $R^{2}$ (model 2) and $R^{2}$ (model 1) or it is equal $\Delta R^{2}$ (model 2)

b $\Delta R^{2}$ of internal financial factors is calculated as the difference of $R^{2}$ (model 3) and $R^{2}$ (model 2) or it is equal $\Delta R^{2}$ (model 3).

$R^{2}$ of external financial factors is calculated as the difference of $R^{2}$ (model 4$)$ and $R^{2}$ (model 3 ) or it is equal $\Delta R^{2}$ (model 4$)$ 
- negative impact-the share of fixed assets in assets.

- Among the tested variables, we identified:

- highly significant positive impact of gross profitability of sales;

- highly significant negative impact of the share of borrowed capital;

- highly significant negative impact of the average interest rates on bank loans;

- the average annual exchange rate of the ruble to the dollar has a positive effect on the net profitability of enterprises in FO and JO (i.e., when the ruble exchange rate falls, their profitability increases) and negatively on enterprises in the RO (i.e., when the ruble exchange rate falls, their profitability decreases).

For enterprises in FO and JO, the main contribution to $R^{2}$ growth is provided by financial factors: internal and external for enterprises in FO, mainly internal-for enterprises in JO. This confirms hypothesis 1.1.

For enterprises in $\mathrm{RO}$, the contribution to the increase in $R^{2}$ (to the increase in the explanatory power of the model) is comparable (approximately the same) to the production efficiency and domestic financial factors. At the same time, the contribution of external financial factors is minimal, although they are significant. We cannot say that the production efficiency gives a greater $R^{2}$ spillage of enterprises in the RO, since this increase is comparable (approximately equal) to the growth of enterprises in the FO. Thus, hypothesis 1.2. is not confirmed. Also, production efficiency has a much smaller impact on $R^{2}$ growth at enterprises in JO.

\subsection{Option 2}

Study of the effect of manufacturing industries on profitability.

The regression models for 6 branches of the manufacturing industry (types of economic activities) are presented in Table 4. The number of enterprises of each form of ownership for each type of economic activity is indicated at the bottom of the table. The coefficients and standard errors are given according to model 7.

Common to all the studied industries are the following consistent patterns on the influence of factors on the profitability of assets:

- high significant positive impact of size of the enterprise;

- highly significant positive impact of gross profitability of sales (a significant increase in the explained variation $R^{2}$ );

- highly significant negative impact of the share of borrowed capital (a significant increase in the explained variation $R^{2}$ ).

At the same time, other factors affect the profitability of the assets of the studied industries in different ways. In particular, the share of fixed assets in assets has a highly significant negative impact on the profitability of the DK, DJ, DL, DA subsections. The value of average interest rates on loans to legal entities has a highly significant negative effect on the profitability of enterprises of all industries except DG, but its effect does not lead to a significant increase in the explained variation $\left(R^{2}\right)$ except for the automotive industry (DM). 
Table 4 Net profitability of assets. Source: calculated by the authors according to data (SPARK: Information system. Interfax (Russia) 2018)

\begin{tabular}{|c|c|c|c|c|c|c|}
\hline Variable & DM & DK & DG & DJ & $\mathrm{DL}$ & DA \\
\hline Size of the enterprise & $6.94(1.22)^{b}$ & $8.14(0.61)^{b}$ & $7.20(0.94)^{b}$ & $6.35(0.59)^{b}$ & $7.44(0.97)^{b}$ & $5.69(0.47)^{b}$ \\
\hline Fixed assets share & $-0.56(0.65)$ & $-1.31(0.37)^{b}$ & $-0.90(0.39)$ & $-1.54(0.32)^{b}$ & $-2.12(0.50)^{b}$ & $-1.10(0.22)^{b}$ \\
\hline Current liquidity ratio & $3.56(3.63)$ & $-0.12(1.46)$ & $-0.09(0.09)$ & $-1.62(0.70)$ & $-0.22(0.11)$ & $0.16(0.20)$ \\
\hline $\begin{array}{l}\text { Gross profitability of } \\
\text { sales }\end{array}$ & $6.65(1.10)^{b}$ & $5.70(0.39)^{b}$ & $4.70(0.53)^{b}$ & $5.12(0.55)^{b}$ & $4.74(0.51)^{b}$ & $4.91(0.37)^{b}$ \\
\hline $\begin{array}{l}\text { Share of borrowed } \\
\text { capital }\end{array}$ & $-4.59(1.06)^{b}$ & $-5.95(0.55)^{b}$ & $-5.84(0.58)^{b}$ & $-5.59(0.48)^{b}$ & $-6.20(0.56)^{b}$ & $-6.76(0.42)^{b}$ \\
\hline Average interest rates & $-1.36(0.21)^{b}$ & $-0.58(0.10)^{b}$ & $-0.32(0.13)$ & $-0.77(0.11)^{b}$ & $-0.48(0.12)^{b}$ & $-0.44(0.08)^{b}$ \\
\hline $\begin{array}{l}\text { Average annual } \\
\text { exchange rate }\end{array}$ & $0.71(0.23)^{a}$ & $-0.04(0.11)$ & $0.26(0.15)$ & $0.08(0.12)$ & $-0.23(0.13)$ & $-0.12(0.09)$ \\
\hline $\begin{array}{l}\text { Gross profitability of } \\
\text { sales * ShareFO }\end{array}$ & $-1.22(0.26)^{b}$ & $-0.39(0.14)^{a}$ & $-0.46(0.16)^{a}$ & $-0.61(0.14)^{b}$ & $-0.43(0.17)$ & $-0.49(0.10)^{b}$ \\
\hline $\begin{array}{l}\text { Share of borrowed } \\
\text { capital * ShareFO }\end{array}$ & $0.05(0.60)$ & $-1.64(0.44)^{b}$ & $-2.09(0.71)^{\mathrm{a}}$ & $-0.65(0.46)$ & $0.84(0.44)$ & $-0.61(0.38)$ \\
\hline $\begin{array}{l}\text { Share of borrowed } \\
\text { capital * ShareFO * } \\
\text { Ruble's deprecia- } \\
\text { tion }\end{array}$ & $-1.47(0.22)^{b}$ & $-0 . .80(0.23)^{b}$ & $-0.94(0.18)^{b}$ & $-0.85(0.15)^{b}$ & $-1.14(0.26)^{b}$ & $-0.43(0.17)$ \\
\hline $\begin{array}{l}\text { Average interest rates } \\
\text { * ShareFO }\end{array}$ & $2.61(0.85)^{a}$ & $-0.01(0.48)$ & $-0.63(0.66)$ & $-0.42(0.46)$ & $1.84(0.49)^{b}$ & $-0.42(0.34)$ \\
\hline $\begin{array}{l}\text { Average annual } \\
\text { exchange rate * } \\
\text { ShareFO }\end{array}$ & $1.00(0.25)^{b}$ & $0.58(0.15)^{b}$ & $0.49(0.16)^{a}$ & $0.38(0.15)$ & $0.30(0.19)$ & $0.08(0.12)$ \\
\hline Intercept & $4.39(0.64)^{b}$ & $7.49(0.21)^{b}$ & $5.01(0.35)^{b}$ & $6.93(0.20)^{b}$ & $6.17(0.22)^{b}$ & $5.41(0.10)^{b}$ \\
\hline Model $1 R^{2}$ & 0.097 & 0.120 & 0.062 & 0.080 & 0.084 & 0.040 \\
\hline Model $2 R^{2}$ & 0.277 & 0.238 & 0.146 & 0.198 & 0.158 & 0.111 \\
\hline Model $3 R^{2}$ & 0.330 & 0.327 & 0.248 & 0.284 & 0.2 .44 & 0.234 \\
\hline Model $4 R^{2}$ & 0.369 & 0.332 & 0.252 & 0.292 & 0.251 & 0.238 \\
\hline Model $5 R^{2}$ & 0.403 & 0.334 & 0.256 & 0.297 & 0.253 & 0.243 \\
\hline Model $6 R^{2}$ & 0.468 & 0.354 & 0.292 & 0.313 & 0.281 & 0.247 \\
\hline Model $7 R^{2}$ & 0.508 & 0.358 & 0.298 & 0.315 & 0.288 & 0.247 \\
\hline $\begin{array}{l}\Delta R^{2} \text { of production } \\
\quad \text { efficiency }\end{array}$ & 0.214 & 0.12 & 0.088 & 0.123 & 0.076 & 0.076 \\
\hline $\begin{array}{l}\Delta R^{2} \text { of financial } \\
\text { factors }\end{array}$ & 0.197 & 0.118 & 0.148 & 0.112 & 0.128 & 0.131 \\
\hline Including_-internal & 0.118 & 0.109 & 0.138 & 0.102 & 0.114 & 0.127 \\
\hline External & 0.079 & 0.009 & 0.01 & 0.01 & 0.014 & 0.004 \\
\hline \multicolumn{7}{|l|}{ Number of enterprises } \\
\hline Total & 303 & 1070 & 728 & 1113 & 869 & 2051 \\
\hline $\mathrm{FO}$ & 56 & 78 & 87 & 73 & 52 & 124 \\
\hline $\mathrm{JO}$ & 25 & 51 & 44 & 58 & 43 & 73 \\
\hline $\mathrm{RO}$ & 222 & 941 & 597 & 982 & 774 & 1854 \\
\hline
\end{tabular}

Regression results (fixed effects estimates, robust estimates)

Standard errors are in parentheses. The coefficients and standard errors are given according to model 7. All constructed models (models no. 1-7) for each type of economic activities are highly significant $(p \ll 0.0001)$

a $\Delta R^{2}$ of production efficiency $=R^{2}$ (model 2$)-R^{2}$ (model 1$)+R^{2}$ (model 5) $-R^{2}$ (model 4$)$. Or it is equal to the sum of $\Delta R^{2}$ (model 2) and $\Delta R^{2}$ (model 5)

b $\Delta R^{2}$ of internal financial factors $=R^{2}$ (model 3$)-R^{2}$ (model 2$)+R^{2}$ (model 6$)-R^{2}$ (model 5$)$. Or it is equal to the sum of $\Delta R^{2}$ (model 3) and $\Delta R^{2}$ (model 6). $R^{2}$ of external financial factors $=R^{2}$ (model 4$)-R^{2}$ (model 3) $+R^{2}$ (model 7$)-R^{2}$ (model 6). Or it is equal to the sum of $\Delta R^{2}$ (model 4$)$ and $\Delta R^{2}$ (model 7) 
In all sectors, except the food industry, a highly significant negative impact on enterprises with foreign participation has been revealed on the factor "Share of borrowed capital * ShareFO * Ruble's depreciation", which leads to a significant increase in the explained variation $\left(R^{2}\right)$. This fact suggests the presence of foreign currency loans or borrowed funds at enterprises in FO and JO of all sectors, except for the food industry.

We identified significant differences in the DM subsection (automobile industry) from other industries both in terms of the share of explained variations $\left(R^{2}=50.8 \%\right)$ and in terms of the influence of variables, including those associated with the share of foreign owners, and their contribution to the increase in $R^{2}$. In this subsection, a significant increase in the explained variation $\left(R^{2}\right)$ is provided by external factors (dynamics of interest rates on loans), as well as factors related to enterprises in foreign and joint ownership. It should be noted that the crisis was the most acute for enterprises in FO and JO of this subsection, and most of them showed losses in 2014-2015.

The findings partially confirm hypothesis No. 2 in relation to 5 branches: DM (automobile industry), DK, DL, DJ, DG. For these branches, enterprises with the participation of foreign capital are characterized by increasing negative impact on the profitability of the share of borrowed capital but weakening the positive impact of gross profitability of sales. In the branch DA (food industry) the share of borrowed capital (share of borrowed capital * ShareFO * Ruble's depreciation) has a significant negative impact $(-0.43$ *), but it is significantly weaker than that of other foreign trade activities.

We also found that production efficiency provides a significant increase in $R^{2}$, comparable to the increase in $R^{2}$ from financial factors in the following industries: DM, DK, DJ. Thus, in a crisis, production efficiency is important in these industries. On the contrary, the main contribution to the growth of $R^{2}$ comes from internal financial factors in the DG, DL, DA industries. The contribution of production efficiency in these industries is significantly lower. External financial factors provide a significant increase in $R^{2}$ only in the automotive industry (DM). Perhaps this is because in this industry the share of enterprises in $\mathrm{FO}$ and JO in the total value of production is high (about 63\%). In other industries, the contribution of external financial factors to $R^{2}$ growth is minimal.

\subsection{Option 3}

\subsubsection{Study of the impact of the share of borrowed capital on profitability}

The regression models for the samples of enterprises with different shares of borrowed capital are presented in Table 5. The number of enterprises for each sample is indicated at the bottom of the table. The coefficients and standard errors are given according to model 7 .

The strength of the influence of the tested variables and the significance of the influence differ significantly depending on the amount of borrowed capital in the balance sheet.

If the share of borrowed capital does not exceed 50\%, the main impact on the net return on assets is provided by the control variables $\left(R^{2}-16.9 \%\right)$ and production efficiency $\left(R^{2}\right.$ increase-10.2\%). The remaining variables (financial factors) provide $R^{2}$ growth by only $3.5 \%$, including: internal financial factors $-2.3 \%$, external financial factors $-1.2 \%$. There are no differences in ownership of this group of enterprises. Variables with * ShareFO, associated with the share of foreign owners are insignificant. The total share of the explained variation in this case is small $\left(R^{2}=30.7 \%\right)$ and practically does not differ from the full sample. 
Table 5 Regression results (fixed effects estimates, robust estimates). Source: calculated by the authors according to data (SPARK: Information system. Interfax (Russia) 2018)

\begin{tabular}{|c|c|c|c|}
\hline Variable & $\begin{array}{l}\text { Full sample } \\
\text { of enterprises }\end{array}$ & $\begin{array}{l}\text { Share of borrowed } \\
\text { capital less } 50 \%\end{array}$ & $\begin{array}{l}\text { Share of borrowed } \\
\text { capital exceeds } \\
50 \%\end{array}$ \\
\hline Size of the enterprise & $6.84(0.30)^{b}$ & $13.77(0.67)^{b}$ & $3.24(0.33)^{b}$ \\
\hline Fixed assets share & $-1.25(0.14)^{b}$ & $-1.97(0.31)^{b}$ & $-1.06(0.19)^{b}$ \\
\hline Current liquidity ratio & $-0.10(0.10)$ & $-0.21(0.06)^{b}$ & $0.58(0.45)$ \\
\hline Gross profitability of sales & $5.14(0.22)^{b}$ & $5.78(0.48)^{\mathrm{b}}$ & $3.47(0.28)^{b}$ \\
\hline Share of borrowed capital & $-6.10(0.23)^{b}$ & $-5.59(0.52)^{b}$ & $-9.46(0.52)^{b}$ \\
\hline Average interest rates & $-0.61(0.05)^{b}$ & $-0.19(0.08)$ & $-0.74(0.06)^{b}$ \\
\hline Average annual exchange rate & $0.03(0.05)$ & $-0.63(0.09)^{b}$ & $0.49(0.07)^{b}$ \\
\hline Gross profitability of sales * ShareFO & $-0.64(0.06)^{b}$ & $-0.16(0.19)$ & $0.20(0.13)$ \\
\hline Share of borrowed capital * ShareFO & $-0.66(0.22)^{\mathrm{a}}$ & $0.70(0.43)$ & $-0.55(0.34)$ \\
\hline $\begin{array}{l}\text { Share of borrowed capital * ShareFO * } \\
\text { Ruble's depreciation }\end{array}$ & $-0.87(0.09)^{b}$ & $0.06(0.14)$ & $-1.39(0.17)^{\mathrm{b}}$ \\
\hline Average interest rates * ShareFO & $0.34(0.28)$ & $1.21(0.69)$ & $-0.07(0.29)$ \\
\hline Average annual exchange rate * ShareFO & $0.47(0.07)^{b}$ & $-0.03(0.14)$ & $0.34(0.10)^{b}$ \\
\hline Intercept & $5.88(0.04)^{b}$ & $5.10(0.65)^{b}$ & $9.04(0.38)^{b}$ \\
\hline Model $1 R^{2}$ & 0.070 & 0.169 & 0.048 \\
\hline Model $2 R^{2}$ & 0.165 & 0.271 & 0.125 \\
\hline Model $3 R^{2}$ & 0.266 & 0.294 & 0.296 \\
\hline Model $4 R^{2}$ & 0.272 & 0.303 & 0.307 \\
\hline Model $5 R^{2}$ & 0.277 & 0.304 & 0.313 \\
\hline Model $6 R^{2}$ & 0.295 & 0.304 & 0.358 \\
\hline Model $7 R^{2}$ & 0.298 & 0.307 & 0.360 \\
\hline$\Delta R^{2}$ of production efficiency ${ }^{\mathrm{a}}$ & 0.1 & 0.103 & 0.083 \\
\hline$\Delta R^{2}$ of financial factors ${ }^{b}$ & 0.128 & 0.035 & 0.229 \\
\hline Including_-internal & 0.119 & 0.023 & 0.216 \\
\hline External & 0.009 & 0.012 & 0.013 \\
\hline \multicolumn{4}{|l|}{ Number of enterprises } \\
\hline Total & 6134 & 1430 & 3073 \\
\hline $\mathrm{FO}$ & 470 & 93 & 226 \\
\hline jO & 294 & 67 & 143 \\
\hline $\mathrm{RO}$ & 5370 & 1270 & 2704 \\
\hline
\end{tabular}

Standard errors are in parentheses. The coefficients and standard errors are given according to model 7. All constructed models (models no. 1-7) are highly significant for all samples $(p \ll 0.0001)$

a $\Delta R^{2}$ of production efficiency $=R^{2}($ model 2$)-R^{2}($ model 1$)+R^{2}($ model 5$)-R^{2}$ (model 4$)$. Or it is equal to the sum of $\Delta R^{2}$ (model 2) and $\Delta R^{2}$ (model 5)

b $\Delta R^{2}$ of internal financial factors $=R^{2}$ (model 3$)-R^{2}$ (model 2$)+R^{2}$ (model 6$)-R^{2}$ (model 5$)$. Or it is equal to the sum of $\Delta R^{2}$ (model 3) and $\Delta R^{2}$ (model 6). $R^{2}$ of external financial factors $=R^{2}$ (model 4$)-R^{2}$ (model 3) $+R^{2}$ (model 7) $-R^{2}$ (model 6). Or it is equal to the sum of $\Delta R^{2}$ (model 4$)$ and $\Delta R^{2}$ (model 7)

If the share of borrowed capital exceeds 50\%, the variables associated with the share of borrowed capital and the share of foreign owners have a major impact on the net return on assets:

- Share of borrowed capital increases $R^{2}$ by $17.1 \%$;

- Share of borrowed capital "ShareFO * Ruble's depreciation increases $R^{2}$ by $4.5 \%$. 
Thus, in this case, financial factors provide an increase of $R^{2} 22.9 \%$, including: internal financial factors $-21.6 \%$, external financial factors $-1.3 \%$. The total share of the explained variation in this case is significantly higher $\left(R^{2}=36 \%\right)$.

Thus, hypothesis No. 3 is confirmed, and the main role is played by domestic financial factors with an increase in the share of borrowed capital. It was revealed that with the deterioration of the liabilities structure of the balance sheet (increase in the share of borrowed capital) the negative influence of financial factors rises, and the share of the variation explained by them grows significantly. On the contrary, the influence of economic factors and control variables weakens significantly, and the share of the variation explained by them decreases.

We note that the share of enterprises whose share of borrowed capital is small (not exceeding $50 \%$ of liabilities annually for $2012-2016$ ) is only $23 \%$ of the entire sample of enterprises (this share practically does not differ in ownership forms). At the same time, the share of enterprises with a large share of borrowed capital (more than 50\% of liabilities annually for 2012-2016) is 50\% of the total sample (differences in ownership patterns are insignificant). Finally, a high share of borrowed capital is characteristic of a significant number of manufacturing enterprises of all forms of ownership in Russia. Our results are generally consistent with existing research in this area (Myers and Majluf 1984; Anwar and Sun 2013; Vy and Tra 2016; Le and Phan 2017). In particular, we have identified the negative impact of the share of borrowed capital on the net return on assets. It is consistent with the Pecking Order Theory, which claims that companies use borrowed funds if they have problems with profitability and do not have enough of their own financial resources. This research underlines the relevance of this problem for countries with unstable economies, in particular, Russia. Analyzing the solid sample of enterprises of the main branches of the manufacturing industry in Russia, we have established their high dependence on borrowed capital. The average and median share of borrowed capital in the liabilities side of the balance are above $60 \%$ (Table 1), and only $23 \%$ of the sampling companies had a share of borrowed capital below $50 \%$ for each year of the study period. Thus, enterprises in countries with unstable economies are highly dependent on borrowed capital. The situation is aggravated by the high level of loan rates in such countries, which increases during crisis periods. There is a vicious circle when enterprises, due to the high cost of loans, cannot increase their profitability and reduce their dependence on borrowed funds. Adjusting the rates on bank loans in times of crisis and actions aimed at systematically reducing these rates are necessary conditions for improving the profitability of enterprises in developing countries with unstable economies.

\section{Conclusions}

1. In the study of the full sample, it was found that enterprises of all forms of ownership have a strong positive effect on the net return on assets of production efficiency and economies of scale and a strong negative impact on the share of borrowed capital, the share of fixed assets in assets and interest rates. The contribution to the increase in $R^{2}$ is comparable to the efficiency of production and domestic financial factors. 
At the same time, the contribution of external financial factors is minimal, although they are significant.

2. For enterprises in FO and JO, the main contribution to $R^{2}$ growth is provided by financial factors: internal and external for enterprises in FO, mostly internal, for enterprises in JO. In enterprises in the RO, the contribution of factors is comparable with the full sample.

3. In the context of industries, it was found that production efficiency provides a significant increase in $R^{2}$, comparable to the increase in financial factors in the sectors: DM, DK, DJ. In contrast, in the DG, DL, DA industries, the main contribution to $R^{2}$ growth comes from internal financial factors. External financial factors provide a significant increase in $R^{2}$ only in the automotive industry. A significant increase in the negative impact of the share of borrowed capital in enterprises with foreign capital (in FO and JO) occurs in all sectors except the food industry.

4. It was found that for enterprises with the share of borrowed funds less than $50 \%$ of liabilities, there are no differences between the forms of ownership, and the main contribution to the increase in $\mathrm{R}^{2}$ ensures production efficiency. On the contrary, for group of enterprises with a share of borrowed capital of more than $50 \%$ of liabilities, one of the main factors determining the profitability of assets are internal financial factors. The impact of external financial factors on improving regression models is negligible. At the same time, a more pronounced negative influence of financial factors is observed in enterprises in FO and JO.

At the same time, our contribution to the research of factors affecting profitability is the consistent patterns that we have identified in relation to groups of factors (production efficiency, internal financial factors, and external financial factors) in an unstable economy. In contrast to other studies of countries with unstable economies (Godart et al. 2012; De Backer and Sleuwaegen 2003; Fu and Wu 2013), this paper contains a comprehensive study of the effect of the above-mentioned groups of factors in the context of industries and forms of ownership of enterprises. The obtained results are useful for effective industrial regulation in developing countries in unstable periods.

We can suggest the following implications for the industry decision-makers as well as policy-makers.

1. In a situation of unstable external environments, based on the Trade-off Theory, enterprises should rely more on their own resources and reduce the share of borrowed capital, while the production scale, ceteris paribus, allows to diversify risks. Also, during periods of instability, the presence of large fixed assets is an additional risk factor for the enterprise. When implementing turnaround measures in stabilization policy, the use of debt instruments should be avoided. Direct repurchase of shares and direct financing of enterprises from state programs is more likely to lead to success.

2. Managers should take into account that during the crisis, the increase in production efficiency in the DM, DK, and DJ industries will be able to compensate for the negative impact of financial factors, while the DG, DL, and DA industries are more vulnerable to financial factors. Managers in the DM (automobile industry) and pol- 
icy-makers should pay special attention to the influence of external factors during the crisis. Under the influence of external factors, enterprises in FO and JO are under substantial stress, which is also true for RO enterprises. This suggests the need for import substitution policies. For industries other than DA (food industry), loans in foreign currency are not recommended. In the DA industry, inferior goods prevail. During the crisis, increased demand for their products can compensate for the instability of foreign currency loans. Policy-makers should pay particular attention to the DG, DL, DA, DM industries because of their greater dependence on environmental factors.

3. In general, companies should not allow the share of borrowed capital to exceed 50\% to ensure that the net return on assets does not depend on financial factors. Otherwise, the share of borrowed capital and the share of foreign owners begin to affect the level of profitability. Nevertheless, the share of the latter in Russian enterprises sample is significant. While implementing the stabilization policy, the state should take into account the need to reduce the share of borrowed capital for leading infrastructure enterprises.

4. For policy-makers, our study suggests that the broad-brush policies aimed at facilitating industrial turnaround policies may be misguided. Based on the differential impact of the studied factors on companies in domestic, joint, or foreign ownership, a careful analysis of the industrial ownership structure is in order before a cohesive set of policy recommendations should be developed. Inasmuch as some sectors of the national economy may be dominated-or at least sufficiently populated-by the firms in joint or foreign ownership, the advancement of policies that aim to assist domestic companies specifically may be ill-advised. Regardless of the ultimate beneficiary domicile, the impact of non-discriminating policies on the domestic workers may be negative. As such, a careful policy planning should take the ownership makeup of the industry firms into consideration.

5. Similarly, given the highly pronounced interindustry differences in the observed effects, effective policies should be industry-specific. This puts a major burden on the policy-makers in that the industry definition in most scholarly research is arbitrary, and depending on the aggregation level the policies deemed effective in some analyses may be deemed counter-effective in others. This calls for a careful sensitivity analysis of the proposed policy changes before any of them can be formalized by the respective agencies.

Nevertheless, our study provides a set of general conclusions and recommendations. In countries with unstable economies, foreign owners should avoid using significant amounts of borrowed capital, and especially loans in foreign currency. On the other hand, with small amounts of borrowing, there were no differences between enterprises with foreign capital and domestic enterprises. The authorities need to make efforts to reduce interest rates on loans to legal entities, since virtually all tested models revealed a highly significant negative impact of the share of borrowed capital and average interest rates on the profitability of industrial enterprises and interest rates are high in countries with unstable economies. 


\section{Acknowledgements}

The research is conducted with the financial support from the Russian Foundation for Basic Research (RFBR) in the frames of scientific and research project of RFBR named "Dynamic modeling of Russian, foreign and joint industrial enterprises development in a situation of economic sanctions", Project No. 17-06-00584(a). The study of the impact of the share of borrowed capital on profitability was carried out with the support of Tomsk Polytechnic University CE Program.

\section{Authors' contributions}

VS is responsible for the hypothesis formulation and their testing, MR applied the methodology and carried out econometric analysis, DV and SA — the theoretical background and policy implications. All authors read and approved the final manuscript.

\section{Authors' information}

Vladislav Spitsin is an associate professor of National Research Tomsk Polytechnic University and Tomsk State University of Control Systems and Radioelectronics. His professional interests are: economies of industries, innovative development and technology transfer, foreign direct investment, industrial development tendencies, regional economy. He is a coauthor of three Certificates of computer programs for solving economic problems. The results of research are presented in local and international publications.

Marina Ryzhkova is a professor in Economics (doctor habilitatus) in Institute of Economics and Management at the National Research Tomsk State University (Russia) and a professor of the School of Engineering Entrepreneurship at the National Research Tomsk Polytechnic University (Russia). Her research interests include revealing of regularities and effects in industrial and public economics by behavioral and experimenting methods. The results are presented in local and international publications.

Darko Vukovic is Professor at Finance and credit department, Faculty of Economics, People's Friendship University of Russia (RUDN University), in Moscow, Russia. Since 2008, Dr. Darko Vukovic works at Geographical Institute "Jovan Cvijic" of the Serbian Academy of Sciences and Arts, at position Chief of Department of regional economics and economic geography.

Sergey Anokhin is a professor in the School of Engineering Entrepreneurship at the National Research Tomsk Polytechnic University in Russia. He also has an appointment at Herberger Business School at St. Cloud State University in the USA. His research interests include entrepreneurship and innovation management in a variety of contexts. His research is extensively published in leading academic journals and is used by policy-makers around the world.

\section{Funding}

This work is supported by RFBR as part of project "Dynamic modeling of Russian, foreign and joint industrial enterprises development in a situation of economic sanctions", Project No. 17-06-00584(a).

\section{Availability of data and materials}

The datasets generated and/or analyzed during the current study are available in the Federal State Statistics Service. Available at http://www.gks.ru/.

\section{Competing interests}

The authors declare that they have no competing interests.

\section{Author details}

${ }^{1}$ School of Engineering Entrepreneurship, National Research Tomsk Polytechnic University, Lenina Avenue, 30, Tomsk 634050, Russia. ${ }^{2}$ Department of Economics, Tomsk State University of Control, Systems and Radioelectronics, Lenina Avenue, 40, Tomsk 634050, Russia. ${ }^{3}$ Economics Department, Institute of Economics and Management, National Research Tomsk State University (Russia), Lenin str. 36, Tomsk 634050, Russia. ${ }^{4}$ Finance and Credit Department, Faculty of Economics, People's Friendship University of Russia (RUDN University), Miklukho-Maklaya str. 6, Moscow 117198, Russia. ${ }^{5}$ Geographical Institute "Jovan Cvijić", Serbian Academy of Sciences and Arts (SASA), Djure Jakšića 9, Belgrade 11000, Serbia. ${ }^{6}$ Department of Management and Entrepreneurship, Herberger Business School, St. Cloud State University, 720 4th Ave S., St. Cloud, MN 56301-4498, USA.

Received: 12 July 2019 Revised: 17 December 2019 Accepted: 18 January 2020

Published online: 04 February 2020

\section{References}

Ahmad F, Draz MU, Yang SC (2016) Exchange rate, economic growth and foreign direct investment in emerging Asian economies: Fresh evidence from long run estimation and variance decomposition approach. June 6. https://papers.ssrn.com/ sol3/papers.cfm?abstract_id=2818181

Ahn SK (2008) Exchange rate fluctuations and firm profitability in Korea. Kukje Kyungje Yongu 14(3):43-72

Aitken BJ, Harrison AE (1999) Do domestic firms benefit from direct foreign investment? Evidence from Venezuela. Am Econ Rev 89(3):605-618

Alti A (2006) How persistent is the impact of market timing on capital structure? J Financ 61 (4):1681-1710

Anwar S, Sun S (2013) Presence of foreign firms and the capital structure of domestic firms: Evidence from China's manufacturing sector? June 10, 2013. https://ssrn.com/abstract=2314956

Anwar S, Sun S (2015) Can the presence of foreign investment affect the capital structure of domestic firms? J Corp Financ 30:32-43 
Baker M, Wurgler J (2002) Market timing and capital structure. J Financ 57(1):1-32

Bamiatzi V, Bozos K, Cavusgil ST, Hult GT, Tomas M (2016) Revisiting the firm, industry, and country effects on profitability under recessionary and expansion periods: a multilevel analysis. Strateg Manag J 37(7):1147-1448

Capon N, Farley JU, Hoenig S (1990) Determinants of financial performance: a meta-analysis. Manag Sci 36(10):1143-1159

Chaddad FR, Mondelli MP (2013) Sources of firm performance differences in the US food economy. J Agric Econ 64(2):382-404

Chatterjee S (2012) The impact of working capital on the profitability: evidence from the Indian firms. SSRN Electron J. August 6. https://papers.ssrn.com/sol3/papers.cfm?abstract_id=2125228

Chhibber PK, Majumdar SK (1999) Foreign ownership and profitability: property rights, control, and the performance of firms in Indian industry. J Law Econ 42(1):209-238

De Backer K, Sleuwaegen L (2003) Does foreign direct investment crowd out domestic entrepreneurship? Rev Ind Organ 22(1):67-84

Fu D, Wu Y (2013) Foreign entry and profitability of domestic firms: evidence from China. Asian Econ Papers 12(2):34-60

Godart O, Görg H, Hanley A (2012) Surviving the crisis: foreign multinationals versus domestic firms. World Econ 35(10):1305-1321

Griffin N 2015. Determinants of firm profitability in Colombia's manufacturing sector: exchange rate or structural? International Monetary Fund. No. 15-97

Gschwandtner A, Hirsch S (2018) What drives firm profitability? A comparison of the US and EU food processing industry. Manch School 86(3):390-416

Habrosh AA (2017) Impact of cash flow, profitability, liquidity, and capital structure ratio on predict financial performance. Adv Sc Lett 23(8):7177-7179

Harrison AE, McMillan MS (2003) Does direct foreign investment affect domestic credit constraints? J Int Econ 61(1):73-100

Hovakimian A (2006) Are observed capital structures determined by equity market timing? J Finan Quant Anal 41 (1):221-243

Interest rates on loans and deposits and the structure of loans and deposits by maturity. Bank of Russia. https://www.cbr.ru/ statistics/?Prtld=int_rat

Jain S, Bhargava A, Bhargava A (2017) Impact of capital structure on profitability of Indian manufacturing firms. Asian J Res Bank Financ 7(7):299-306

Jeanneret A (2015) International firm investment under exchange rate uncertainty. Rev Financ 20(5):2015-2048

Kisgen DJ (2006) Credit ratings and capital structure. J Financ 61(3):1035-1072

Kosová R (2010) Do foreign firms crowd out domestic firms? Evidence from the Czech Republic. Rev Econ Stat 92(4):861-881

Kraus A, Litzenberger RH (1973) A state-preference model of optimal financial leverage. J Financ 28:911-922

Le TPV, Phan TB (2017) Capital structure and firm performance: empirical evidence from a small transition country. Res Int Bus Financ 42:710-726

Marquardt DW (1980) You should standardize the predictor variables in your regression models. J Am Stat Assoc 75(369):87-91

Myers SC, Majluf NS (1984) Corporate financing and investment decisions when firms have information that investors do not have. J Financ Econ 13(2):187-221

Negasa T 2016. The effect of capital structure on firms' profitability (Evidenced from Ethiopian). Preprints 2016, 2016070013. https://www.preprints.org/manuscript/201607.0013/v1

Russia in Figures. Federal State Statistics Service. http://www.gks.ru/

Shapiro DM (1983) The comparative profitability of Canadian and foreign controlled firms. Manag Decis Econ 4(2):97-106

Shyam-Sunder L, Myers SC (1999) Testing static tradeoff against pecking order models of capital structure. J Financ Econ 51(2):219-244

SPARK: Information system. Interfax (Russia) (2018) https://spark-interfax.com/

Spitsin V, Mikhalchuk A, Spitsina L, Vukovic DB (2018) Foreign-owned companies in countries with an unstable economy: the case of the automotive industry in Russia. J Int Stud 11(3):57-69. https://doi.org/10.14254/2071-8330.2018/11-3/5

Tang B (2015) Exchange rate exposure of Chinese firms at the industry and firm level. Rev Dev Econ 19(3):592-607

Tirole J (1988) The theory of industrial organization. MIT Press, Cambridge

Vaicondam Y, Ramakrishnan S (2017) Capital structure and profitability across Malaysian listed firms. Adv Sci Lett 23(9):9275-9278

Vithessonthi C, Tongurai I (2015a) The effect of firm size on the leverage-performance relationship during the financial crisis of 2007-2009. J Multinatl Financ Manag 29:1-29

Vithessonthi C, Tongurai J (2015b) The effect of leverage on performance: domestically-oriented versus internationallyoriented firms. Res Int Bus Financ 34:265-280

Vu MC, Phan TT (2016) Working capital management and firm profitability during a period of financial crisis: empirical study in emerging country of Vietnam. Advances in Social Sciences Research Journal 3(3). http://www.sseuk.org/index.php/ ASSRJ/article/view/1816/1073

Vukovic D, Lapshina K, Maiti M (2019) European Monetary Union Bond Market Dynamics: Pre \& Post Crisis. Res Int Bus Financ 50:369-380. https://doi.org/10.1016/j.ribaf.2019.04.001

Vukovic D, Ugolnikov V, Moinak M (2020) Analyst says a lot but should you listen: evidence from Russia. J Econ Stud. https:// doi.org/10.1108/jes-10-2018-0352

Vy N, Tra N (2016) Does profitability affect debt ratio? Evidence from Vietnam listed firms. J Financ Econ Res 1(2):89-103

Welge MK, Al-Laham A (2008) Strategisches management. Gabler, Wiesbaden

Yapa Abeywardhana D (2017) Capital structure theory: an overview. Account Financ Res 6(1):133-138

Yurtoglu BB (2004) Persistence of firm-level profitability in Turkey. Appl Econ 36(6):615-625

Zakari M (2017) The impact of exchange rate fluctuations on foreign direct investment in Nigeria. J Financ Account $5(4): 165-170$

\section{Publisher's Note}

Springer Nature remains neutral with regard to jurisdictional claims in published maps and institutional affiliations. 